\title{
Effects of Skill, Independency, Objectivity and Audit Work Experience on the Quality of Audit Outcome with Audit Ethics as a Moderating Variable in the Inspectorate Office of Karo Regency
}

\author{
Wahyudi Pialanta Ginting S ${ }^{1}$, Iskandar Muda ${ }^{1}$, Yeni Absah ${ }^{1}$ \\ ${ }^{1}$ Department of Accounting, Faculty of Economics and Business at Universitas Sumatera Utara, Indonesia.
}

Corresponding Author: Wahyudi Pialanta Ginting S

DOI: https://doi.org/10.52403/ijrr.20220230

\begin{abstract}
The quality of audit outcome is a reflection of the action of an auditor who audits based on auditing standard and reports it with adequate evidence to the stakeholders. The objective of the research is to find out the influence of skill, independency, objectivity, and audit work experience, with audit ethics as a moderating variable in the Inspectorate Office of Karo Regency. The population was auditors and functional officials in the Inspectorate Office of Karo Regency.

The population is made up of 48 auditors and functional officials in the Inspectorate Office of Karo Regency. Primary data are analyzed by using Partial Least Square (PLS) approach.

The result of the research shows that independency has positive and significant effects on the quality of audit outcome. Skill, objectivity, and audit work experience do not have any significant effects on the quality of internal audit outcome. It is also found that audit ethics owned by auditors cannot strengthen the effects of skill, independency, objectivity, and audit work experience on the audit quality in the Inspectorate Office of Karo Regency.
\end{abstract}

Keywords: skill, Independency, objectivity, audit work experience, audit ethics, quality of audit outcome

\section{INTRODUCTION}

In supporting the creation of good governance, three main aspects are needed, namely supervision, control, and inspection.
Supervision is an activity carried out by parties outside the executive, namely the community and the Regional People's Representative Council, which oversee government performance. Control is a mechanism carried out by the executive to ensure that management systems and policies are implemented properly so that organizational goals can be adequately achieved. The examination is an activity carried out by parties who have independency and have the professional expertise to check whether the results of government performance are following the standards set (Mardiasmo, 2002).

A government auditor carries out supervising and examining the management of state finances in Indonesia. In the scope of the regional government, the Regency/City Regional Inspectorate is the front line in preventing and overcoming the practice of corruption, collusion, and nepotism (CCN) (Hamzah, 2017). In carrying out its primary duties and functions, the Inspectorate conducts routine inspections of all existing local government agencies. With this inspection, hoping that the activities carried out can go well, criminal mistakes and acts that can endanger the state can be reduced. With good performance in the inspection field, the quality of audit outcome also increases. 
In fulfilling quality audit outcome, a code of ethics and general standards are needed for auditors in carrying out their obligations. The code of ethics is intended to maintain the auditor's behavior in carrying out his duties. In contrast, the Audit Standards are intended to maintain the quality of the audit outcome carried out by the auditor. With these regulations, the public or report users can assess the extent to which government auditors have worked by established standards and ethics.

The Code of Ethics for Government Internal Supervisory Apparatus generally refers to PERMENPAN No. PER/04/M.PAN/03/2008. One of its objectives is to prevent unethical behavior from occurring to fulfill the principles of accountable work and implement audit controls to create a credible auditor with optimal performance in auditing. The behavioral principles that an auditor should have to produce quality audit outcome include expertise, independency, objectivity, and audit work experience. An expert auditor is needed so that an auditor can understand the task as well as possible to produce quality audit outcome; independency is needed so that the auditor acts reasonably, impartially, or cannot be suspected of being partial, so as not to harm any party; objectivity is required so that auditors are believed not to subject their judgment on audit matters to others; as well as audit work experience in auditors which makes auditors more professional and wise in producing higher quality audit reports.

Public sector audit standards, especially the Government Internal Supervisory Apparatus, generally refer to PERMENPAN No. PER/05/M.PAN/03/ 2008. Following the general standard in PERMENPAN No. PER/05/M.PAN/03/ 2008 that auditors are required to have sufficient expertise in the profession they are engaged in and must meet technical qualifications and experience in the field they are involved in. An auditor who has adequate expertise will better understand and know various problems in greater depth, and it will be easier to follow increasingly complex developments in his audit environment.

General standard No. 2200

(PERMENPAN No. PER/05/M.PAN/03/ 2008) states that "Auditors must have the knowledge, skills, and other competencies needed to carry out their responsibilities." The definition of expertise in auditing standards includes formal education and technical training in accounting and auditing. In conducting an audit, an auditor must have good personal qualities, adequate knowledge, and special expertise in their field. Competence relates to the professional expertise possessed by the auditor as a result of formal education, professional examinations, and participation in training, seminars, symposiums. Competence makes the auditor more sensitive and more able to make appropriate decisions. The data or audit outcome taken by the auditor can be relied on by the users of the audit outcome.

The auditor's independent attitude includes several aspects: independency is an auditor's ability to be free, honest, and objective in carrying out audit assignments. To maintain independency in the facts, the auditor must maintain his freedom of attitude must always be honest in using his knowledge. Thus, in reality, a free (independent) mental attitude can be interpreted as an impartial honesty in formulating and expressing his opinion. It means that in considering the facts used as the basis for giving an opinion, the auditor must be objective and not prejudiced. Independency in appearance is seen from parties interested in the audited company who know the relationship between the auditor and his client. The auditor will be considered not independent in appearance if the auditor has a specific relationship with his client, which may give rise to a suspicion that the auditor will side with his client or not. (Munawir, 1995).

An attitude of objectivity must accompany the attitude of independency of an auditor. Objectivity is an unbiased mental attitude that allows internal auditors 
to carry out assignments to believe in the results of their work and believe there is no compromise. Objectivity requires that internal auditors not subordinate their judgment on audit matters to others.

The attitude of objectivity of an APIP auditor is regulated in the general standard no. 2120 (PERMENPAN No. PER/05/M.PAN/03/2008), which states that "Auditors must have a neutral and unbiased attitude and avoid conflicts of interest in planning, carrying out and reporting the work they do." The auditor must be objective in carrying out the audit. The principle of objectivity requires that the auditor performs the audit honestly and does not compromise on quality. The APIP leadership is not allowed to place the auditor in a situation that makes the auditor unable to make decisions based on professional considerations.

In addition to expertise, independency, and objectivity, the auditor's audit work experience also dramatically influences the Quality of Audit Outcome. (Purnamasari, 2005) concludes that an auditor with high audit work experience will have advantages in several ways, including 1) detecting errors, 2) understanding errors, and 3) looking for causes of errors. An inexperienced auditor is likely to make a more significant error attribution than an experienced auditor, affecting the quality of audit outcome.

The experience of an auditor will continue to increase along with the increasing number of audits carried out and the complexity of the audited company's financial transactions to increase and expand knowledge in the field of accounting and auditing. Experience also impacts every decision taken in implementing the audit, so it is hoped that it is correct. It indicates that the longer the tenure and experience of an auditor, the better the quality of the audit outcome produced.

Supervision is an act of seeking information about what is being carried out in an agency being examined, comparing the results with the established criteria, and approving or rejecting the results by providing recommendations on corrective actions. Examinations conducted by Government Internal Supervisory Apparatus sometimes encounter obstacles in their implementation where there is a sense of kinship, togetherness, and human considerations that are too prominent. Another problem faced in improving the quality of Government Internal Supervisory Apparatus is how to improve attitudes/behaviors the ability of the supervisory apparatus to carry out inspections so that the supervision carried out can run fairly, effectively, and efficiently (Tarigan, 2011).

One of the units that conduct audits/inspections of regional governments is the regional Inspectorate, which has the task of carrying out general supervision of regional governments and other tasks assigned by regional heads so that in their duties, the Inspectorate is the same the internal auditor. According to Boynton (2001), the function of internal auditors is to assist organizational management in providing effective accountability. In addition, internal auditors are also expected to contribute to improving efficiency and effectiveness to improve administrative work. Thus, local government auditors play a crucial role in creating accountability and transparency in financial management in the regions.

In this study, audit ethics is a moderating variable. Ethics is concerned with how people behave towards each other (Kell et al., 2002). Such high expectations on applying ethics for the public accounting profession is crucial that clients and external parties who use financial statements have confidence in the quality of audits and other services provided by public accountants (Lubis, 2015). If the auditor's ethics is getting better, it will affect his attitude in carrying out audit duties to improve the quality of the audit outcome.

Several factors influence the attitude and behavior of auditors, including religiosity, education, organizational, 
emotional quotient, family environment, life experience, rewards received, law, and position or position (Riduan, 2012). We can learn how important ethics are in every activity, especially for auditors. The more obedient the auditor is to the code of ethics, the higher the quality of the audit outcome.

The phenomenon that occurs today is related to the performance of the Inspectorate in inspection activities. Namely, the implementation of coaching and supervision performance has not met the established standards (limited personnel, time and number of supervisory tasks, and other tasks), leadership policies have not considered the results of supervisory performance, and lack of authority. The Inspectorate is an internal supervisory apparatus, so this causes the auditee/work unit to be less responsive to the results of the Inspectorate's supervision (BPK RI, 2013).

This research was conducted in Karo Regency due to a decrease in the quality of reports produced by auditors. It can be seen from the opinion given by the Audit Board on the results of the Regional Government Financial Report examination, namely during the 2014 - 2018 fiscal year, the Inspectorate Office of Karo Regency always received a Qualified Opinion (Fair with Exceptions). The assessment is based on several findings contained in the Regional Government Financial Report so that it becomes a problem that the regional government must follow up. These findings are found in financial reporting that is not following Government Accounting Standards, weaknesses in the Internal Control System, and several findings related to non-compliance with laws and regulations (BPK Representative of North Sumatra Province, 2016). On the other hand, the weak capacity of the Inspectorate can be seen from the BPK report, which states that there is still an unfinished Inspection Result Recommendation Report of the Audit Board for Fiscal Year 2004.

In addition, during 2014-2018, the Inspectorate Office of Karo Regency could only handle 481 Inspection Results Recommendation Reports of the Audit Board out of 686 submitted by the audit board to the Local Government Budget of Karo Regency. Based on the report, the Karo Regency Inspectorate could only handle about $73.32 \%$ of the reports recommended by the audit board. This paper is very far from the achievements made by Toba Samosir Regency, which followed up on the Inspection Results Recommendation Reports of Audit Board report by $90 \%$.

Audit board's Representatives of North Sumatra Province (2019) said the Inspection Results Recommendation Reports of Audit Board of Republic Indonesia on the Regional Government Financial Statements of the 2014-2018 Budget Year against the Inspectorate Office of Karo Regency were as follows:

Table 1. The Results of the BPK Opinion

\begin{tabular}{|l|l|l|}
\hline No & Regency / Year & Opinion \\
\hline 1 & Karo Regency / 2014 & Qualified Opinion \\
\hline 2 & Karo Regency / 2015 & Qualified Opinion \\
\hline 3 & Karo Regency / 2016 & Disclaimer \\
\hline 4 & Karo Regency / 2017 & Qualified Opinion \\
\hline 5 & Karo Regency / 2018 & Qualified Opinion \\
\hline
\end{tabular}

This condition is caused because there are still areas in the implementation of government that are not ready with a new system of government to hold local government following good governance. There are many cases in several areas relating to the problem of corruption, irregularities, abuse of authority and office, violations, and many other criminal cases.

In addition to the consecutive qualified opinion received, in 2016, the Inspectorate Office of Karo Regency obtained a very significant decline in the Audit Board opinion, namely accepting the disclaimer opinion. Based on the Inspection Results Recommendation Reports by the Audit Board of Republic Indonesia on the financial statements of the Karo District Government of the 2016 budget, which contained the disclaimer opinion submitted to contain the recommendations of the Audit Board, which was directly addressed to the Inspectorate Office of Karo Regency on the 
findings of a 63 billion grant budget assistance for Mount Sinabung refugees. At the position of December 31, 2016, the Rp183 billion had no more in the regional treasury because it had been transferred to the treasurer of the BPBD expenditure and from the treasurer of expenditure in the transfer of the 60 groups of settler farmers. However, there is still Rp. Ninety-four billion in cash in the settler farmers account so that the new budget is spent around Rp. 89 billion. As a result of the obscurity of the use of funds that are not following SPI standards, the Inspectorate Office of Karo Regency only reports the number of funds without attaching existing evidence so that the audit board cannot accept the report.

As a result, the audit board recommended that "the Inspectorate Office of Karo Regency immediately conduct an audit of the recipient of the grant that has not submitted the responsibility of the 2016 Social Assistance and Grant Funds and reported the results to the governor to be targeted according to the provisions". On this recommendation, the auditor of the Inspectorate Office of Karo Regency is expected to be more professional and improve its performance to obtain quality audits.

The gap between the report produced by the Inspectorate with the audit board also often occurs. It is reflected in the weak auditor's capabilities in completing a recommendation report. In addition, other factors influence it, namely non-compliance in financial management following SPI standards and reports presented by the auditor is not following the standard of reporting Government Accounting Standards. It caused a gap between the report presented by the Inspectorate and the field's situation found by the audit board. During 2014-2018, there were many irregularities in the field, not reported by the Inspectorate but found by the audit board. Among them are:

1. Cash Explary on the Expenditure Treasurer at Kabanjahe Hospital,
2. Administration of inventory in the Public Health Center is not orderly and not according to the Standard Operating Procedures (SOP),

3. Land and building taxes management is inadequate and not according to the SOP,

4. Integration of fixed assets that are not orderly and the calculation of permanent assets depreciation that has not referred to accounting policies and Government Accounting Standards,

5. The realization of school operational aid expenditure is not orderly, inadequate, and not according to the SOP.

The lack of maximum quality of the examination produced in the Inspectorate Office of Karo Regency may be due to the lack of auditor staff at the Inspectorate Office of Karo Regency. Not all of the auditor staff registered with the Inspectorate Office of Karo Regency have an educational background that follows the field of work, so it is considered less essential abilities in terms of examination.

Based on the gap between the results of the research and the problems presented above, researchers are interested in researching on: "Effect of expertise, independency, objectivity and audit work experience of audit work on the quality outcome of examinations with audit ethics as a moderating variable in the Inspectorate Office of Karo Regency."

\section{Previous Research}

This study was also based on different studies that differed in expertise, independency, objectivity, and audit work experience on the quality of audit outcome with audit ethics as a moderating variable.

Tambunan (2010) researched the effect of expertise on 38 employees of the Inspectorate of North Tapanuli Regency and proved that skill affected the quality of the audit outcome. Other studies were also carried out by Pohan (2014) against 82 employees of the North Sumatra Province Inspectorate and proved that skill had a significant positive effect on the quality of 
audit outcome. This research was also supported by Ashari (2011), Herman et al. (2015), and Ramlan (2018). However, it is different from Syafitri's (2014) and Samsi's (2013) research, which states that expertise does not affect the quality of audit outcome.

Pike (2003) says that when the auditor is not independent, the desire to produce high-quality audits is low because the auditor does not make serious efforts to identify material misstatements. When there are identified, the auditor will not always report them. Elisa (2010), Ashari (2011), and Lubis (2015) argue that independency affects the quality of audit outcome. Unlike the research conducted by Emmerisa (2015), which argues that independency does not affect the quality of audit outcome.

The objectivity of Silaen Research (2016) and Anhariani (2006) argue that objectivity affects the quality of audit outcome. Unlike the research conducted by Lubis (2015), which states that objectivity does not affect the quality of audit outcome.

Komang et al. (2014), Dewi (2013), and Purnami (2014) stated that audit work experience affected the quality of the outcome of the audit. Unlike the research conducted by Ahmad (2015), which states that audit work experience does not affect the quality of audit outcome.

Lubis's (2015) research states that audit ethics influence the quality of audit outcome. Riduan (2012) states that audit ethics does not affect the quality of audit outcome. Based on the results of previous studies regarding factors that can affect the quality of audit outcome, it can be seen that internal auditors' expertise, independency, objectivity, and audit work experience have not fully indicated consistent results.

\section{Framework}

Following the description of the background of the problem, literature review, and previous research, a conceptual research framework is prepared as follows:

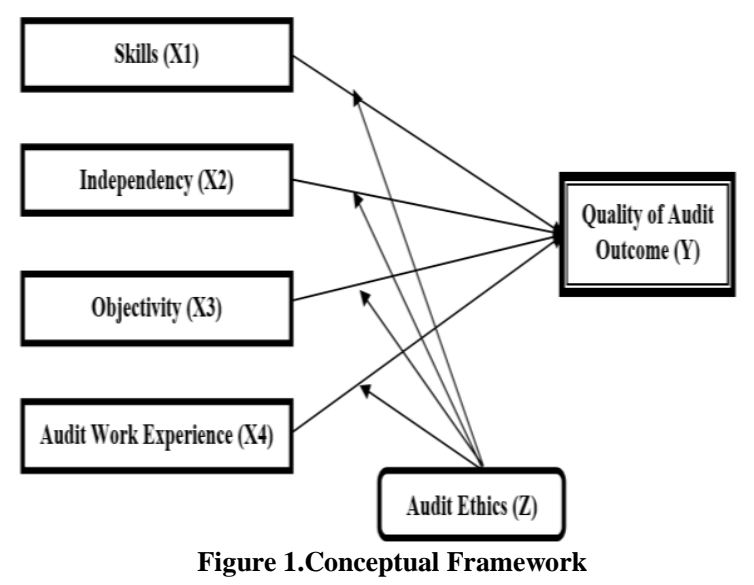

H1: The expertise positively affects the quality of audit outcome in the Inspectorate Office of Karo Regency.

$\mathrm{H} 2$ : Independency positively affects the quality of audit outcome in the Inspectorate Office of Karo Regency.

H3: Objectivity positively affects the quality of audit outcome in the Inspectorate Office of Karo Regency.

H4: Auditor audit work experience positively affects the quality of audit outcome in the Inspectorate Office of Karo Regency.

H5: The auditor's ethics can moderate the effect of auditor expertise on the quality of audit outcome in the Inspectorate Office of Karo Regency.

H6: Ethics Auditors can moderate the influence of the auditor's independency on the quality of audit outcome in the Inspectorate Office of Karo Regency.

H7: Ethics Auditor can moderate the influence of the auditor's objectivity on the quality of the audit outcome in the Inspectorate Office of Karo Regency.

H8: Ethics Auditor can moderate the effect of auditor audit work experience on the quality of audit outcome in the Inspectorate Office of Karo Regency.

\section{RESEARCH METHODS}

This type of research is causal associative research to determine the factors of is Skill, Independency, Objectivity, and Audit Work Experience As an independent variable on the quality of audit outcome in the Inspectorate Office of Karo Regency as a 
dependent variable with audit ethics as a moderating variable. The causal associative study aims to analyze the relationship between one variable and another to know how one variable affects other variables (Erlina, 2011). The data collection technique used is a questionnaire (questionnaire). The data analysis method is used in this study is a statistical analysis method using the Smartpls application. Data analysis performs by testing standard assumptions and testing hypotheses.

The population in this study was the staff of the Inspectorate Office of Karo Regency. In this study, the sample used was 48 people of the inspectorate apparatus. The sampling method used is a saturated sample (census) technique, namely the sampling technique by making all population members a sample (Arikunto, 1988).

\section{RESULT AND DISCUSSION \\ Descriptive Statistical Analysis}

Descriptive statistical analysis of research is used to provide an overview of the variables used in research that describe respondents' perceptions or opinions on the questions submitted.

\begin{tabular}{|c|c|c|c|c|c|}
\hline & $\mathrm{N}$ & Minimum & Maximum & Mean & Std. Deviation \\
\hline TOTAL.X1 & 48 & 31 & 40 & 34.08 & 2.774 \\
\hline TOTALXX2 & 48 & 26 & 35 & 29,81 & 2,811 \\
\hline TOTAL.X3 & 48 & 18 & 24 & 19,50 & 1,891 \\
\hline TOTAL.X4 & 48 & 17 & 25 & 21,00 & 2,000 \\
\hline TOTAL.Y & 48 & 27 & 34 & 29,50 & 2,222 \\
\hline TOTAL.Z & 48 & 28 & 35 & 30,85 & 2,423 \\
\hline Valid N (listwise) & 48 & & & & \\
\hline
\end{tabular}

Based on the results of the data tabulation on 48 questionnaires that have been collected, it can be concluded that the results of this study are pretty well due to the mean value obtained being more significant than the standard deviation value. The standard deviation is used as a reference because the standard deviation value reflects research data deviations. The meaning value more significant than the standard deviation value indicates that the data deployment shows normal results and does not cause bias.
In addition to descriptive statistical tables, the following are also presented frequency distribution tables that display internal auditor answers related to questions submitted. In compiling the frequency distribution table, all the data collected will be grouped and searched for the average to know the strength of each variable. The results of the average class interval were determined to determine the data interpretation category (Durianto et al. In Ladia, 2009). The following is the determination of the interval class which applies to all variables:

The lowest value in the sum is 45 , and the highest value is 225 .

Class intervals are $(225-45) / 5=36$.

Class determination is:

Value of $190-225=$ Very good

Value 154-189= Good

Value $116-153=$ Neutral

Value $82-117=$ Not good

Value 45-81 = Very not good

The frequency distribution obtained from 48 respondents' answers regarding the research variable is presented in the following table:

Table 3. Frequency Distribution Table

\begin{tabular}{|l|l|l|l|}
\hline No. & Categories & Interval & Frequency \\
\hline 1 & Very Good & $190-225$ & 14 \\
\hline 2 & Good & $154-189$ & 34 \\
\hline 3 & Neutral & $116-153$ & 0 \\
\hline 4 & Not Good & $82-117$ & 0 \\
\hline 5 & Bad & $45-81$ & 0 \\
\hline \multicolumn{3}{|c|}{ Source: Primary data processed using SPSS }
\end{tabular}

Based on the table, it can be concluded that the internal auditor working at the Inspectorate Office of Karo Regency is competent in his field. It is seen from the frequency of good auditors, indicating that internal auditors have a good understanding or perception in answering questionnaire questions.

\section{Testing Results of The Measurement Model (Outer Model)}

Evaluation of the measurement model (Outer Model) is a correlation evaluation between the construct and its indicators by testing the validity and 
Wahyudi Pialanta Ginting S et.al. Effects of skill, independency, objectivity and audit work experience on the quality of audit outcome with audit ethics as a moderating variable in the inspectorate office of Karo Regency.

reliability of the indicators of latent variables formed by the confirmatory factor analysis (CFA). The construct validity test shows how well the results obtained from using a measurement according to the theories used to define a construct.

Construct validity consists of Convergent Validity and Discriminant Validity. Besides the construct validity test, it is also carried out a reliability construct test measured by the Composite Reliability of the indicator block that measures the construct because the composite reliability measures the actual value of the reliability of a construct.

The Outer Test Model starts with estimating or estimating parameters, namely by calculating pls algorithms with the following results:

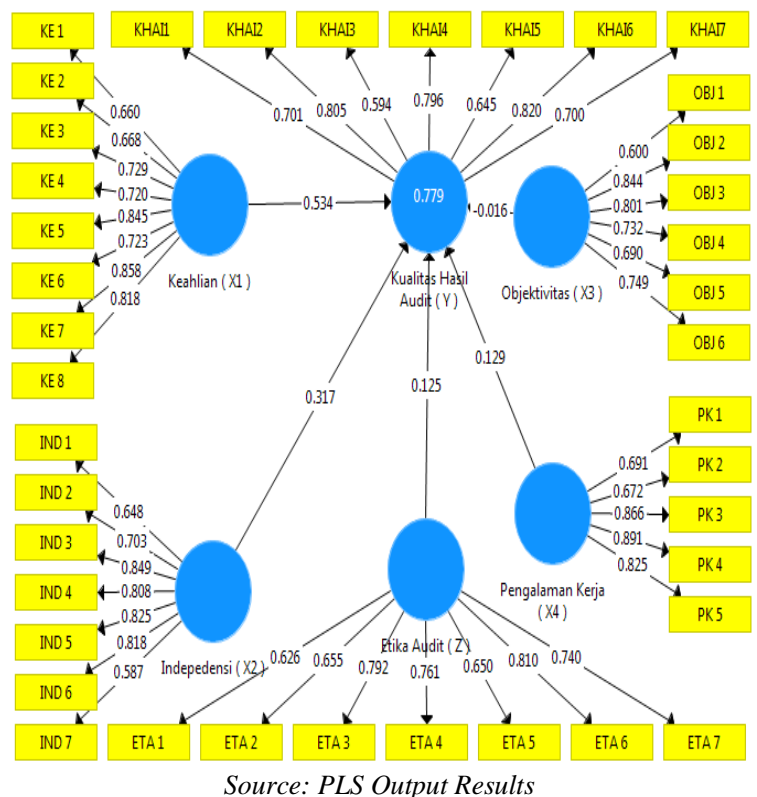

Figure 2. PLS Algorithm Calculation Output Display

\section{Convergent Validity Test Results}

Convergent validity test is done by looking at the loading factor value of each construct. The loading factor value above 0.7 is stated as an ideal or valid size as an indicator in measuring the construct. The value of 0.5 to 0.6 is still acceptable, while the value below 0.5 must be removed from the model (Ghozali 2008). Based on data calculations with the algorithm PLS, method.
Based on Figure 2, it can be seen that the entire loading value of factors in the variable has greater than 0.5 , which means the indicator is declared valid, so it has been worth using in this study.

\section{Discriminant Validity Test Results}

Discriminant Validity testing is carried out to prove whether the construct indicator will have the most significant loading factor on the construct formed from the loading factor with another construct. Discriminant Validity of the reflection indicator can be seen from the Cross Loading value between the indicator and the constrain.

Here is the Cross Loading value of the results of the PLS Algorithm Smart PLS program can be seen in the following table 4:

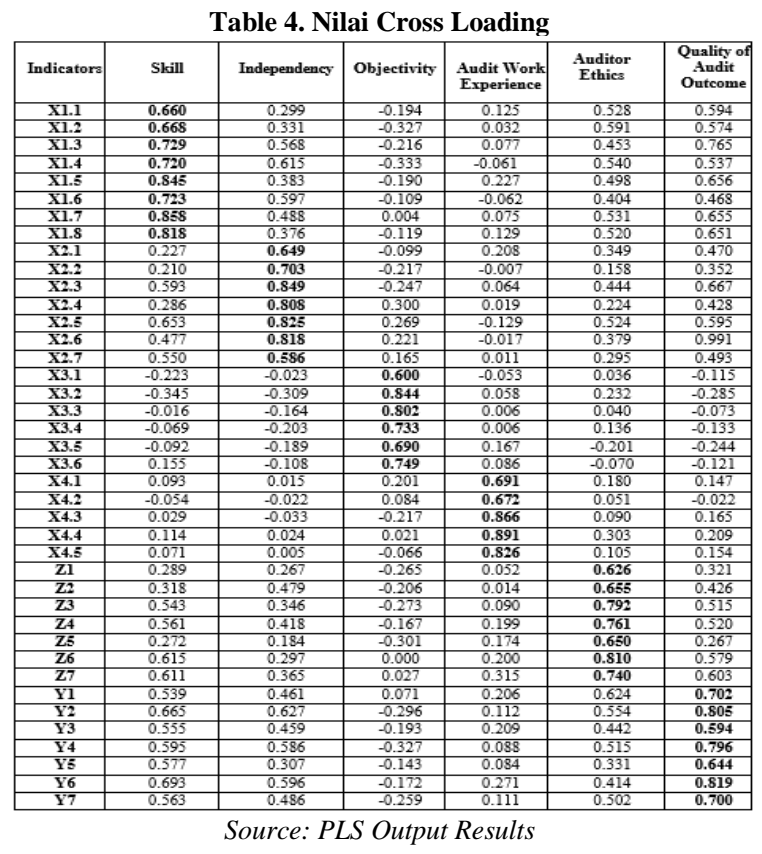

Based on the Cross Loading value in the table below, it can be concluded that the correlation of each indicator with the construction is higher than the other constructs and has a Value of Cross Loadings $>0.5$ as a fulfillment of discriminant validity. It shows that latent constructs can predict their blocks better than other blocks and valid block indicators. 
Wahyudi Pialanta Ginting S et.al. Effects of skill, independency, objectivity and audit work experience on the quality of audit outcome with audit ethics as a moderating variable in the inspectorate office of Karo Regency.

\section{Reliability Test Results}

In measuring the reliability of constructs with reflective indicators, this study was conducted with Composite Reliability. Composite reliability measures the actual value of the reliability of a construct, the Rule of Thumb used to assess the reliability of the construct, namely the composite reliability value must be greater than 0.7 for confirmatory research (Ghozali and Batuan 2015). The reliability test results on each variable can be seen on tables as follows:

\begin{tabular}{|l|l|l|}
\hline Table 5. Composite Reliability Value \\
\hline & $\begin{array}{l}\text { Composite } \\
\text { Reliability }\end{array}$ & Descriptions \\
\hline Skill & 0.914 & Reliable \\
\hline Independency & 0.901 & Reliable \\
\hline Objectivity & 0.878 & Reliable \\
\hline Audit Work Experience & 0.894 & Reliable \\
\hline Auditor Ethics & 0.883 & Reliable \\
\hline $\begin{array}{l}\text { Quality of Internal Audit } \\
\text { Outcome }\end{array}$ & 0.886 & Reliable \\
\hline
\end{tabular}

Based on table 5 above, it can be seen that the composite reliability value of each construct is above 0.70 , so it can be stated that the indicator used in this study has fulfilled a good (reliable) reliability.

\section{Extracted Average Variance Value (AVE)}

In addition to the loading factor value, it is necessary to know the average variance extracted (AVE) value to meet convergent validity. If the root value of the AVE squared is higher than the correlation value between constructs, it is declared to meet the Discriminant Validity (Ghozali \& Batan, 2015).

Ave values are presented in the following table 6 obtained from output PLS algorithm:

Table 6. Extracted Average Variance Value (AVE)

\begin{tabular}{|l|l|l|}
\hline Variables & AVE Value & Descriptions \\
\hline Skill & 0.572 & Valid \\
\hline Independency & 0.569 & Valid \\
\hline Objectivity & 0.548 & Valid \\
\hline Audit Work Experience & 0.631 & Valid \\
\hline Auditor Ethics & 0.522 & Valid \\
\hline Quality of Internal Audit Outcome & 0.529 & Valid \\
\hline \multicolumn{2}{|c}{ Source: PLS Output Results }
\end{tabular}

Provisions regarding the measurement parameters (rule of thumb) measurement model (Outer Model) that AVE is considered to have fulfilled convergent validity if Ave is more significant than 0.50 (Ghozali and Batuan 2015). So based on the AVE table, it can be seen that the value of the AVE for each construct has been valid. So the construct has met convergent validity.

\section{Alpha Cronbach Value}

Table 7 shows that Cronbach's Alpha values are every variable above the 0.700 thresholds. All variable instruments can be reliable, which means consistency if used by other researchers.

\begin{tabular}{|c|c|c|}
\hline Variables & $\begin{array}{l}\text { Cronbach } \\
\text { Alpha }\end{array}$ & Descriptions \\
\hline Skill & 0.891 & Reliable \\
\hline Independency & 0.871 & Reliable \\
\hline Objectivity & 0.839 & Reliable \\
\hline $\begin{array}{l}\text { Audit Work Experience } \\
\text { eexperience }\end{array}$ & 0.865 & Reliable \\
\hline Auditor Ethics & 0.850 & Reliable \\
\hline $\begin{array}{l}\text { Quality of Internal Audit } \\
\text { Outcome }\end{array}$ & 0.848 & Reliable \\
\hline
\end{tabular}

\section{Classic Assumption Test Normality Test}

This test aims to test whether, in the regression model, disturbing or residual variables have a normal distribution. A good regression model is a data that is normally distributed or close to normal. The method used is with Kolmogorov Smirnov statistics. Data testing uses the One-Sample Kolmogorov-Smirnov Test by looking at a significance level of $5 \%$. The basis of decision-making in the normality test is by looking at the probability of asymp.sig (2tailed), which is greater than 0.05 , the data can be said to be normally distributed (Ghozali, 2013), as can be seen in Table 8 .

Table 8. Normality Test

\begin{tabular}{|l|l|l|}
\hline Samples & Kolmogorov-Smirnov & asymp.sig (2-tailed) \\
\hline 48 & 0,078 & 0,200 \\
\hline \multicolumn{2}{|c|}{ Source: Research Results, 2021 (data processed using SPSS) }
\end{tabular}

Based on table 8 , it can be seen that the value of Kolmogorov-Smirnov is 0.078 with a significant level in ASYMP. Sig. (2 
Wahyudi Pialanta Ginting S et.al. Effects of skill, independency, objectivity and audit work experience on the quality of audit outcome with audit ethics as a moderating variable in the inspectorate office of Karo Regency.

tailed) of 0.200 greater than 0.05 , it can be concluded that the data is normally distributed.

Data normality testing can also be known by looking at graphics and abnormal distribution curves. The following is a test of the results of data normality in the form of a P-P curve.

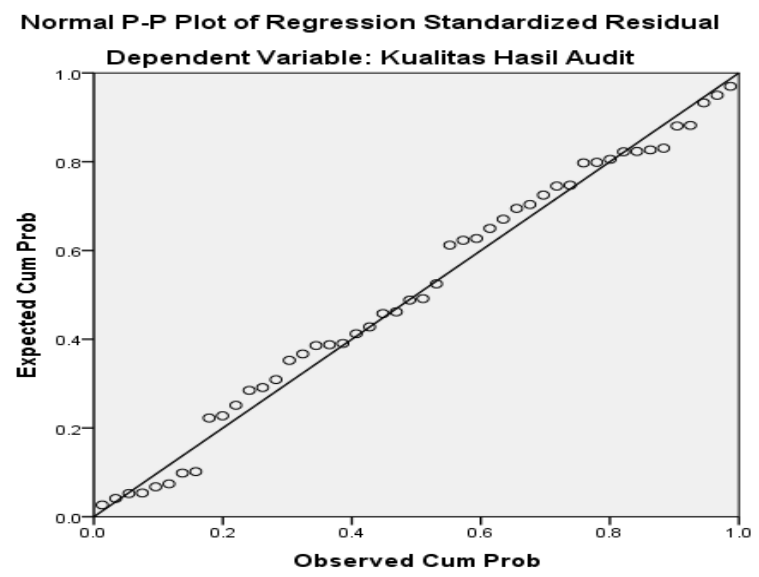

Source: Research Results, 2021 (data processed using SPSS) Figure 3. Data Normality Testing

Based on the PP-Plots curve image in Figure 3, it can be concluded that the curve is normally distributed.

\section{Multicollinearity Testing}

The multicollinearity test aims to test the correlation between independent variables. If there is a correlation, there are multicollinearity symptoms. A good regression model should not occur correlation between its independent variables.

Table 9. Multicollinearity Test Results

\begin{tabular}{|l|l|l|}
\hline Variables & Tolerance & VIF \\
\hline Skill & .489 & 2.044 \\
\hline Independency & .627 & 1.595 \\
\hline Objectivity & .922 & 1.084 \\
\hline Audit Work Experience & .952 & 1.051 \\
\hline \multicolumn{2}{|c|}{ Source: Research Results, 2021 (data processed using SPSS) }
\end{tabular}

\section{Test Criteria:}

1. The presence of multicollinearity if the tolerance value $<0$ or VIF value $>10$.

2. The absence of multicollinearity when the tolerance value $>0$ or VIF value $<10$.

From the table above, it can be seen that the tolerance value is above 0 and the VIF value $<10$, so it can be concluded that there is no multicollinearity.
Structural Model Testing Results (Inner Models)

\section{The Results of The Path Analysis (Path Analysis)}

After the model is estimated to meet the convergent validity criteria, discriminate validity, and reliability, the ideal model has been obtained following the conceptual framework of research. Structural model testing (inner model) was tested. Assessing Inner Model is to see the statistical t value of each path to see the relationship between latent constructs by looking at the results of the estimated coefficient of the PATH parameter and its significance level (Ghozali, 2008).

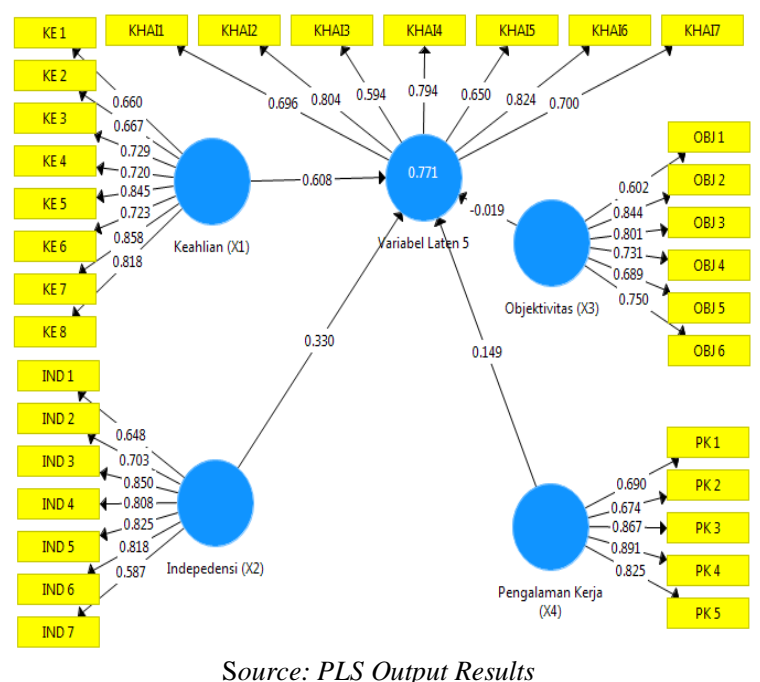

Figure 4. Output Display Calculation PLS Algorithm Before Moderation

Based on the output of Algorithm output in Figure 4, it is known that the adjusted r-square value in the model of 0.771. It means the expertise variable, independency, objectivity, and audit work experience can explain the quality of the internal audit outcome of $77.1 \%$. The remaining $22.9 \%$ is influenced by variables not found in the research model.

Then the structural equation is formed as follows:

Quality of Audit Outcome $=\mathbf{0 . 6 0 8}$

Expertise + 0.330 Independency - 0.019

Objectivity + 0.149 Audit work experience

Based on the above equation, it can be explained that the coefficient value of 
expertise variables (X1), independency (X2), and audit work experience (X4) each is positive. This value can be interpreted that expertise variables (X1), independency (X2), and audit work experience (X4) have a positive effect on the quality variables of the internal audit outcome (Y). It means that if the above variables are increasing, it will further improve the quality of the internal audit outcome.

While the coefficient value of objectivity variables (X3) is negative, this value can be interpreted that the objectivity variables (X3) negatively affecting the quality variables of the internal audit outcome (Y). It means that if the objectivity variable (X3) increases, it will reduce the quality of the internal audit outcome.

The results of PLS the Smart PLS program algorithm in assessing the moderating variables can be seen in the following figure:

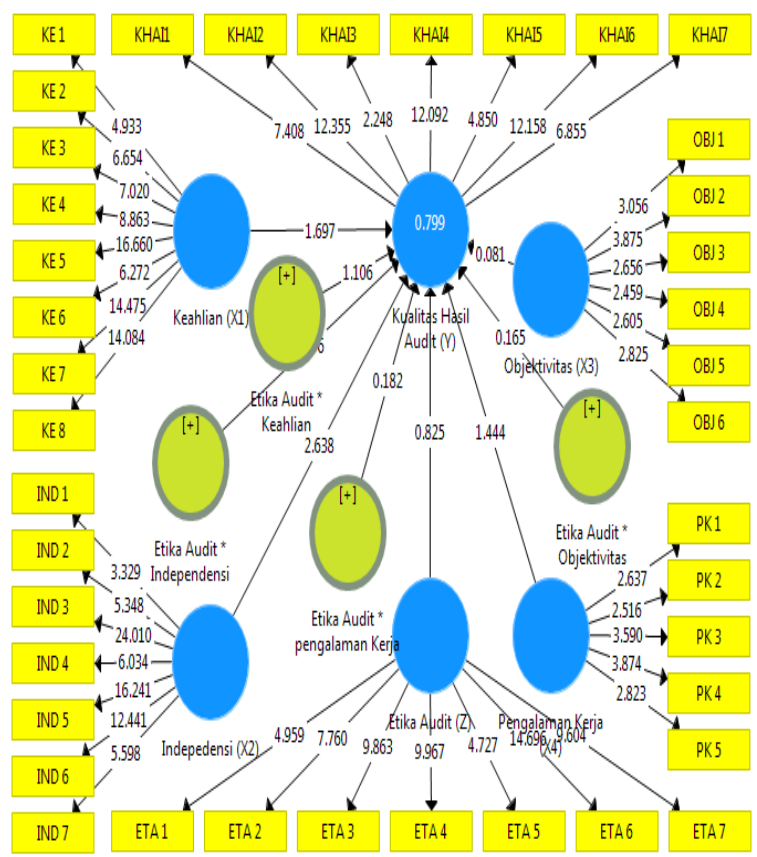

Source: PLS Output Results

Figure 5.The Output Display of Calculation PLS Algorithm After Moderation

Based on the path diagram in the V.5 image, the most dominant factor in influencing the quality of the internal audit outcome (Y) is the effect of independency (X2), with the highest lane coefficient of 2,875 .
Based on the Figure 5, structural equations can be formed as follows:

Quality of Audit Outcome = 1,683

Expertise $+2,875$ Independency $+\mathbf{0 . 0 8 5}$

Objectivity $+1,391$ Audit work

experience + 1,170 Ethics * Expertise +

0.343 Ethics * Independency $+\mathbf{0 . 1 6 0}$

Ethics * Objectivity +0.01 Ethics * Audit work experience $+\mathbf{0 . 1 9 6}$

Audit Ethics Variables * Expertise, Ethics Audit * Independency, Ethics Audit * Objectivity and Audit Ethics * Each audit work experience has a positive coefficient. This value can be interpreted if the audit ethics * expertise, audit ethics * Independency, audit ethics * objectivity, and audit ethics * Audit work experience positively influences the quality of internal audit outcome. It means that the ethics possessed by the auditor can strengthen the relationship between expertise variables, independency, the objectivity of audit work experience with the quality of internal audit outcome.

\section{Determination Coefficient (R2)}

Based on the output PLS algorithm in Figure 5 obtained R-Square in the model of 0.799 means audit ethics * Expertise, audit ethics * Independency, audit ethics * objectivity and audit ethics * Audit work experience can explain the quality of audit outcome by $79 \%$. The remaining $21 \%$ is influenced by other variables not found in this research model. Based on the results of the PLS it has been done, the value is 0.799 , which means this study has a strong model.

\section{Effect Size (F2) Test Results}

The effect size (F2) value shows the interaction between the independent and moderating variables in influencing the dependent variables. Calculation of Effect Size (F2) is used to measure the contribution between each variable against $\mathrm{R} 2$ by looking at the $\mathrm{F} 2$ value of $0.02,0.15$, and 0.35 , which indicates that the model is slight, moderate, and significant (Ghozali 2008). The formula can calculate calculation of Effect Size: 
Wahyudi Pialanta Ginting S et.al. Effects of skill, independency, objectivity and audit work experience on the quality of audit outcome with audit ethics as a moderating variable in the inspectorate office of Karo Regency.

f2 $=\underline{\text { R2 Moderation Model }- \text { R2 Models Without Moderation }}$

1 - R2 Moderation Model

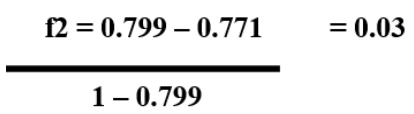

Based on the calculation above effect size, variable audit work experience provides a minimal effect on the quality of the internal audit outcome valued at 0,03 .

\section{Prediction Relevance Test Results $(Q$ Square)}

Prediction relevance (Q Square), known as Stone- Geisser's, determines the prediction capability with blindfolding procedures. It can only be done for endogenous constructs with reflective indicators. If the value obtained is 0.02 (weak), 0.15 (moderate), and 0.35 (strong) (Ghozali 2008). The Q2 value range is 0 $<$ Q2 $<1$, where the model is getting better if the $\mathrm{Q} 2$ value is getting closer to 1 .

Calculations can be counted with $\mathrm{Q}$ Square formula:

$\mathrm{Q} 2=1-(1-\mathrm{R} 12)-(1-\mathrm{R} 22)$

Based on the value of R-Square from the results of PLS can be calculated by the value of $\mathrm{Q}$ on this research model, as follows:

$\mathrm{Q} 2=1-(1-0.799)-(1-0.771)$

$=0.55$.

Based on the Q2 Square calculation results above, it is obtained by Q2 of 0.55 , which means the research model has an extensive prediction capability. Namely, the magnitude of the diversity of research data can be explained by the structural equation model developed in this study amounting to $55 \%$, and other factors outside the model explain the remaining $45 \%$. The Q2 value shows that the modeling variable model in this research model has solid predictive relevance. The Q2 value range is $0<0.555$ $<1$, where the model is getting better if the Q2 value is getting closer to 1 .

\section{Hypothesis Test Results}

Hypothesis testing looks at the tstatistical value resulting from the bootstrapping process. The hypothesis is accepted (supported) if the T-statistical value is greater than 1.96 with a significant level of 5\% (two-tailed).

The results of the Bootstrapping process of the SmartPLS program can be seen in Table 9 as follows:

Tabel 9. T - Statistics Value

\begin{tabular}{|l|l|l|l|l|l|}
\hline Exogenous & Endogenous & Path Analysis & T Statistic & P-Value & Description \\
\hline $\mathrm{X} 1$ & $\mathrm{Y}$ & 0.408 & 1.683 & 0.093 & Rejected \\
\hline $\mathrm{X} 2$ & $\mathrm{Y}$ & 0.324 & 2.875 & 0.006 & Accepted \\
\hline $\mathrm{X} 3$ & $\mathrm{Y}$ & -0.008 & 0.085 & 0.933 & Rejected \\
\hline $\mathrm{X} 4$ & $\mathrm{Y}$ & 0.133 & 1.040 & 0.149 & Rejected \\
\hline $\mathrm{Z}^{*} \mathrm{X} 1$ & $\mathrm{Y}$ & 0.180 & 1.170 & 0.242 & Rejected \\
\hline $\mathrm{Z}^{*} \mathrm{X} 2$ & $\mathrm{Y}$ & -0.043 & 0.343 & 0.732 & Rejected \\
\hline $\mathrm{Z}^{*} \mathrm{X} 3$ & $\mathrm{Y}$ & 0.016 & 0.160 & 0.873 & Rejected \\
\hline $\mathrm{Z}^{*} \mathrm{X} 4$ & $\mathrm{Y}$ & -0.019 & 0.165 & 1.391 & Rejected \\
\hline \multicolumn{7}{|l|}{ Source: PLS Output Results } \\
\end{tabular}

\section{CONCLUSION}

Based on the results of data analysis and research discussion, it can be concluded as follows:

1. Auditor's expertise does not affect the quality of internal audit outcome in the Inspectorate Office of Karo Regency.

2. The auditor's independency has a positive and significant effect on the quality of internal audit outcome in the Inspectorate Office of Karo Regency.
3. The auditor's objectivity does not affect the quality of the internal audit outcome in the Inspectorate Office of Karo Regency.

4. The audit work experience of the auditor does not affect the quality of the outcome of internal audits in the Inspectorate Office of Karo Regency.

5. The Ethics Audit Auditor cannot moderate the relationship between expertise on the quality of internal audit 
outcome in the Inspectorate Office of Karo Regency.

6. Audit Ethics Auditors cannot moderate the relationship between independency on the quality of internal audit outcome in the Inspectorate Office of Karo Regency.

7. Audit Ethics Audit cannot moderate the relationship between the objectivity of the quality of internal audit outcome in the Inspectorate Office of Karo Regency.

8. Audit Ethics cannot moderate the relationship between audit work experience on the quality of internal audit outcome in the Inspectorate Office of Karo Regency.

\section{RESEARCH LIMITATIONS}

In this study using research instruments in the form of questionnaires, there is still the possibility of weaknesses encountered. Such as less detailed answers, respondents who answered originals, dishonest and preliminary questions, or less understood by respondents and researchers who did not know whether the questionnaire was filled by the respondent concerned.

\section{SUGGESTION}

Based on limitations in his research which was put forward, researchers expect this research to be valuable as input. Some suggestions of researchers are as follows:

1. The research population is limited to internal auditors working on the Inspectorate Office of Karo Regency. They have participated in the training to improve the expertise and auditor's ability to be less generalized, and the number of auditors is minimal.

2. This study also has other limitations, namely the number of variables studied. The variables studied are only related to expertise, independency, ethics, objectivity, and audit work experience owned by the auditor in producing audit quality without considering other variables that might affect audit quality.

3. The method used is a survey method using a questionnaire. The results of the answers obtained are only based on the perception of each auditor.

4. Other limitations, namely the number of variables that have no effect in this study, may also be caused by too few variable measurement indicators not measuring the variables correctly. The measurement indicator was due to a large number of invalid indicators due to the inconsistency of respondents when answering the questionnaire.

\section{Acknowledgement: None}

\section{Conflict of Interest: None}

\section{Source of Funding: None}

\section{REFERENCES}

1. Agung, A.M Lilik. 2007. "Human Capital Competencies: Sketsa-Sketsa Praktik Human Capital Berbasis Kompetensi", Penerbit PT. Elex Media Komputindo, Jakarta.

2. Ashari, Ruslan 2011. "Pengaruh Keahlian, Indepedensi, dan Etika Auditor Pada Inspektorat Provinsi Maluku Utara". Skripsi, Fakultas Ekonomi Universitas Hasanuddin. Juni 2011

3. Boynton, Wiliam C., Johnson, Raymond N \& Walter G. Kell., 2001. "Modern, Auditing", $7^{\text {th }}$ Edition, New York: John Wiley \& Sons, Inc.

4. De Angelo, L.E. 1981. Auditor Independence, "Low Balling", and Disclosure Regulation. Journal of Accounting and Economics 3. Agustus.

5. De Angelo, L.E. 1981. Auditor Size and and Audit Quality. Agustus. Journal of Accounting and Economics. Desember.

6. Dewi, Kadek dan Yasa. 2016. "Pengaruh Good Corporate Governance, Profitabilitas, Likuiditas, dan Solvabilitas terhadap Peringkat Obligasi". ISSN: 2302-8556 E-Jurnal Akuntansi Universitas Udayana, Vol. 16.2. Agustus 2016.

7. Djamil, Nasrullah, 2001: Faktor-faktor yang Mempengaruhi Kualitas Audit pada Sektor Publik dan Beberapa Karakteristik 
Wahyudi Pialanta Ginting S et.al. Effects of skill, independency, objectivity and audit work experience on the quality of audit outcome with audit ethics as a moderating variable in the inspectorate office of Karo Regency.

untuk Meningkatkannya, STIE Nasional Banjarmasin.

8. Ely Suhayati, Sri Dewi Anggadini. 2009. Akuntansi Keuangan, Edisi Pertama, Yogyakarta:Graha Ilmu.

9. Emmerisa 2015. "Pengaruh Kompetensi, Indepedensi, Due Profesional Care, Akuntabilitas, dan Fraud Risk Assessmentaparat Inspektorat Terhadap Kualitas Audit Dalam Mewujudkan Good Governance di Kabupaten Karo". Skripsi, Fakultas Ekonomi Universitas Sumatera Utara. Maret 2015.

10. Erlina. 2011. Metodologi Penelitian. Medan: USU Press.

11. Ghozali, Imam. 2008. Model Persamaan Struktural: Konsep Dan Aplikasi

12. Ghozali, Imam. 2013. Aplikasi Analisis Multivariate Dengan Program SPSS. 7th ed. Semarang: Badan Penerbit Universitas Diponegoro.

13. Ghozali, Imam, and H Latan. 2015. Partial Least Square, Konsep, Teknik Dan Aplikasi Menggunakan Program Smartpls 3.0 Untuk Penelitian Empiris. Semarang: Badan Penerbit Universitas Diponegoro.

14. Hasniati, Deddy T. Tikson dan Muhammad Hamzah Syahruddin, 2017, "Peningkatan Kesadaran Masyarakat Dalam Pengawasan Dana Desa Di Kecamatan Mappaksunggu", Jurnal Abdimas, Vol 21 No 2.

15. Heider, F. 1958. The psychology of interpersonal relations. John Wiley \& Sons Inc. https://doi.org/10.1037/10628000

16. Husein, Umar 2008, Metode Penelitian Untuk Skripsi dan Tesis Bisnis. Jakarta: PT Raja Grafindo Persada.

17. Jaafar, H.T Redwan dan Sumiyati, 2005, Kode Etik dan Standar Audit, Diklat Pembentukan Auditor Terampil, Pusat Pendidikan dan Pelatihan Pengawasan BPKP, Jakarta.

18. Jelic, Milos. 2012. The Impact of Ethics on Quality Audit Result. International Journal for Quality Research. Vol. 6. No. 4.

19. Jensen, M., C., dan W. Meckling, 1976. ${ }^{a}$ Theory of the firm: Managerial behavior, agency cost and ownership structure ${ }^{\circ}$,
Journal of Finance Economic 3:305- 360, di-download

dari

http://www.nhh.no/for/courses/spring/eco 420/jensen- meckling-76.pdf.

20. Lubis, Arini Ashal 2015. "Pengaruh Pengalaman Kerja, Indepedensi, Objektivitas, Integritas, Kompetensi, dan Etika Auditor Terhadap Kulitas Hasil Pemeriksaan Aitor BPKP Prov.Sumut". Tesis, Fakultas Ekonomi Universitas Sumatera Utara. 9, Februari 2015

21. Mardiasmo. 2002. Perubahan Dalam Perusahaan, Tantangan Atau Ancaman? Andi. Yogyakarta.

22. Munawir. H.S. 1995. "Uditing Modern", Edisi Pertama, Penerbit BPFE, Yogyakarta.

23. Pike, Joel. E. 2003. "Studies On Audit Quality". Disertasi, University Of Wisconsin - Madison, 12 Juni 2003.

24. Pohan, Nur Aisah .2014. "Analisis Pengaruh Keahlian, Indepedensi, Perencanaan Audit dan Supervisi Audit Terhadap Kualitas Audit Dengan Motivasi Sebagai Variabel Moderating". Tesis, Fakultas Ekonomi Universitas Sumatera Utara. 21, Juli 2014.

25. Purnamasari. 2005. Pengaruh Pengalaman Kerja terhadap Hubungan Partisipasi dengan Efektivitas Sistem Informasi. Jurnal Riset Akuntansi Keuangan. Vol.1 No.3.

26. Purnamasari, St. Vena. 2005. "Sifat Machiavellian dan Pertimbangan Etis: Anteseden Independensi dan Perilaku Etis Auditor"Jurnal. SNA IX. Padang.

27. Robbins, Stephen P. dan Timothy A. Judge. 2008. Perilaku Organisasi Edisi ke12, Jakarta: Salemba Empat.

28. Rown, V. L., Gissel, J. L., \& Gordon Neely, D. 2016. Audit quality indicators: perceptions of junior-level auditors. Managerial Auditing Journal, 31(8/9), 949-980. doi:10.1108/maj-01-2016-1300.

29. Sawyer,L,B.,. Dottenhoferm M. A dan Scheiner J.H.2006. Sawyers internal auditing, Buku 1, Edisi 5, Jakarta: Penerjemah Desi Anhariani, Salemba Empat.

30. Silaen, Bernando D. 2016, "Faktor-Faktor Yang Mempengaruhi Kualitas Hasil Audit Dengan Perencanaan Audit Sebagai 
Wahyudi Pialanta Ginting S et.al. Effects of skill, independency, objectivity and audit work experience on the quality of audit outcome with audit ethics as a moderating variable in the inspectorate office of Karo Regency.

Variabel Moderating Pada Inspektorat Kabupaten Simalungun". Tesis, Universitas Sumatera Utara. 18 Agustus 2016.

31. Suseno, Novie Susanti 2013, “An empirical analysis of auditor independenceand audit fees on audit quality",International Journal of Managementand Business Studies ISSN: 2167-0439Vol. 3(3). March.

32. Sri Lastanti, Hexana. 2005. Tinjauan Terhadap Kompetensi dan Independensi Akuntan Publik: Refleksi Atas Skandal Keuangan. Media Riset Akuntansi, Auditing dan Informasi Vol. 5 No. 1 April 2005.

33. Tambunan, Toman Sony. 2010. "Pengaruh Keahlian Audit dan Indepedensi Pemeriksa Terhadap Kualitas Hasil Pemeriksaan di Inspektorat Kabupaten Tapanuli Utara”. Tesis,
Fakultas Ekonomi Universitas Sumatera Utara. 10, Maret 2010.

34. Tarigan, Sabri. 2011. "Pengaruh Pengalaman Kerja, Indepedensi, Objektivitas,Integritas dan Kompetensi Terhadap Kualitas Hasil Pemeriksaan". Tesis. Fakultas Ekonomi Universitas Sumatera Utara. 18, Februari 2011.

35. Tugiman, Hiro. 2006. Standar profesional audit internal. Yogyakarta: Kanisius.

How to cite this article: Wahyudi Pialanta Ginting S, Iskandar Muda, Yeni Absah. Effects of skill, independency, objectivity and audit work experience on the quality of audit outcome with audit ethics as a moderating variable in the inspectorate office of Karo Regency. International Journal of Research and Review. 2022; 9(2): 209-223. DOI: https://doi.org/10.52403/ijrr.20220230 